\section{Long-term Effects of Training Systems and Rootstocks on 'McIntosh' and 'Honeycrisp' Performance, a 15-year Study in a Northern Cold Climate- Part 1: Agronomic Analysis}

\author{
Jaume Lordan ${ }^{2}$ \\ Department of Horticulture, NYSAES, Cornell University, Geneva, NY 14456
}

Anna Wallis ${ }^{1}$

Cornell Cooperative Extension, Eastern NY Commercial Horticulture Program, Cornell University, Plattsburgh, NY 12901

Poliana Francescatto and Terence L. Robinson Department of Horticulture, NYSAES, Cornell University, Geneva, NY 14456

Additional index words. crop load, fruit quality, Malus $\times$ domestica, tree size, yield, yield efficiency, cold climate apple, eastern North America

\begin{abstract}
Choice of cultivar, training system, planting density, and rootstock affect orchard performance and profitability. To provide guidance to growers in northern cold climates on these choices, a field trial was established in Peru, Clinton County, NY, in 2002, with two apple cultivars (Honeycrisp and McIntosh). From 2002 through 2016, we compared Central Leader on 'M.M.111'; Slender Pyramid on 'M.26' and 'Geneva ${ }^{\circledR}$ 30' ('G.30'); Vertical Axis on 'M.9 (Nic ${ }^{\circledR}$ 29)' ('M.9'), 'Budagovsky 9' ('B.9'), and 'G.16'; SolAxe on 'M.9', 'B.9', and 'G.16'; and Tall Spindle on 'M.9', 'B.9', and 'G.16'. Central Leader was planted at 539 trees/ha, Slender Pyramid at 1097 trees/ha, Vertical Axis and SolAxe at 1794 trees/ha, and Tall Spindle at 3230 trees/ha. Cumulative yield was higher with 'McIntosh' than with 'Honeycrisp'. High planting densities (Tall Spindle) gave the highest cumulative yields (593 t.ha' ${ }^{-1}$ on 'McIntosh' and $341 \mathrm{t} \cdot \mathrm{ha}^{-1}$ on 'Honeycrisp'). Tall Spindle (3230 trees/ha) on 'M.9' appeared to be the best option for 'McIntosh'. On the other hand, for a weak-growing cultivar such as 'Honeycrisp', Tall Spindle on 'B.9' (366 t.ha $\left.{ }^{-1}\right)$ and Slender Pyramid (1097 trees/ha) on 'G.30' (354 t.ha ${ }^{-1}$ ) were the two combinations with the highest cumulative yield, largest fruit size (220-235 g), and greatest efficiency index $\left(4.6-3.9 \mathrm{~kg} \cdot \mathrm{cm}^{-2}\right)$.
\end{abstract}

The success of a new orchard investment depends on yield performance and the market value of the crop. Therefore, factors such as cultivar, rootstock, training system, planting density, precocity, and fruit quality, and price play key roles in overall orchard profitability (Bravin et al., 2009; DeMaree, 1995; DeMarree et al., 2003; Elkins et al., 2008; Goedegebure, 1993; Heijerman et al., 2015; Robinson et al.,

Received for publication 26 Jan. 2018. Accepted for publication 24 Apr. 2018.

This research was partially supported by the New York Apple Research Development Program.

We wish to thank Everett Orchards for all the resources invested in this trial. We thank Peter Herzeelle for field and laboratory support. The authors also acknowledge Kevin Iungerman, Cornell Cooperative Extension, Eastern NY Commercial Horticulture Program for his contributions to this research.

${ }^{1}$ Currently at Plant Pathology and Plant-Microbe Biology, Plant Science, Cornell University, Ithaca, NY 14850.

${ }^{2}$ Corresponding author. E-mail: j13325@cornell. edu. density can decrease orchard profitability (Lordan et al., 2017a; Robinson, 2008a; Robinson et al., 2007). Dwarfing apple rootstocks, especially 'M.9' and 'M.26', have made possible the transition of entire fruitgrowing sectors to higher tree density and training systems over the last 50 years. New varieties such as Honeycrisp require a reevaluation of promising rootstocks because the scion cultivar has low vigor (Robinson et al., 2011b). The Geneva Apple Rootstock Breeding Program has developed rootstock genotypes that are better adapted to biotic stresses common in eastern North America (Cummins and Aldwinckle, 1983; Fazio et al., 2015). Among them, 'G.30' has been especially useful in cold climates with short growing seasons, whereas ' $\mathrm{G} .16$ ' has a similar growth and vigor to 'M.9' clones (Autio et al., 2011; Robinson and Hoying, 2004; Robinson et al., 2003).

Most orchards in New York State are replanted on old orchard sites. The severity of apple replant disease (ARD) is not known although research efforts by Merwin et al. (2001) have attempted to assess the problem. In addition, recent regulations on fumigation have resulted in not a single licensed fumigation company working in New York State. Rootstock resistance to ARD could be a more sustainable solution to ARD than fumigation. Several of the Geneva ${ }^{\circledR}$ rootstocks have shown some tolerance to ARD, especially 'G.30' (Fazio et al., 2015; Kviklys et al., 2016; Robinson et al., 2012).

Northern cold climates with fewer heat units result in slower tree growth and usually lower yield than more temperate climates with more heat units (Robinson et al., 2011a). This has meant that much of the data on orchard system performance is not directly applicable to colder growing regions.

Because there are many different factors that affect orchard profitability (Badiu et al., 2015; Balkhoven-Baart et al., 2000; Bradshaw et al., 2016; Lordan et al., 2018b; Sojkova and Adamickova, 2011; Weber, 2001) there is a need to evaluate performance for different situations of climate cultivar, training system, rootstock, planting density, location, and economic condition.

This project was intentionally performed in a cold climate on old orchard soil without fumigation to simulate the actual orchard replanting carried out in northern New York State and to determine if any combination of rootstock and planting system could be successful in both the climatic conditions and the old orchard soil conditions of northern New York. In addition, the aim of this study was to evaluate the orchard performance of the new cold-hardy cultivar, Honeycrisp, compared with the standard cold hardy cultivar, McIntosh, at a wide range of planting densities, training systems, and rootstocks for cold areas.

\section{Materials and Methods} planting density (Elkins and Dejong, 2002; Kappel and Brownlee, 2001; Robinson, 2008b; Sansavini and Musacchi, 2002; Vercammen, 1999), it is worth noting that there is a point where increasing planting
Trial site and design. In 2002 an onfarm field trial was planted in Peru, Clinton County, NY (lat. $44.597223^{\circ}$, long. 
$-73.545078^{\circ}$ ), with two apple cultivars (Honeycrisp and McIntosh). We compared the following (12) production systems: Central Leader (CL) on 'M.M.111' rootstock; Slender Pyramid (SP) on 'M.26' and 'Geneva ${ }^{\circledR}$ 30' ('G.30'); Vertical Axis (VA) on 'M.9 (Nic ${ }^{\circledR}$ 29)' ('M.9'), 'Budagovsky 9' ('B.9') and 'G.16'; SolAxe (SA) on 'M.9', 'B.9', and 'G.16'; and Tall Spindle (TS) on 'M.9', 'B.9', and 'G.16' (Table 1). CL was planted at 539 trees/ha, SP at 1097 trees/ha, VA and SA at 1794 trees/ha, and TS at 3230 trees/ha (Robinson, 2003). Experimental design was a randomized complete block with a splitsplit plot and three replications. Training system was the main plot with each main plot consisting of two (CL), four (SP), or six (VA, SA, and TS) 40-m-long rows. Cultivar was the subplot, which consisted of one (CL), two (SP), or three (VA, SA, and TS) 40-mlong rows. Rootstock was the sub-subplot with each sub-subplot consisting of a single 40-m row. There were 72 rows of $40 \mathrm{~m}$ each with 24 rows in each replication containing randomized main plots (system), randomized subplots (cultivar) within the main plots, and randomized sub-subplots (rootstock) within the subplots. The treatment structure was an incomplete factorial of four systems, two cultivars, and six rootstocks with only 24 out a possible 48 combinations of cultivar $\times$ training system $\times$ rootstock. The number of trees in each sub-subplot depended on tree spacing and varied from 13 trees/row for CL, 18 for SP, 25 for SA and VA, and 38 for TS. Soil type was a Bombay loam with good water-holding capacity, moderately well drained and fertile (USDA, 2018). The site had previously been planted with apple trees on seedling rootstock spaced $6 \times 12 \mathrm{~m}$ for 40 years and was not fumigated. The replant disease severity at the trial site was not evaluated before planting, but field fumigation trials in the same county by Merwin et al. (2001) showed low to moderate replant disease pressure for similar soils. The soil was tilled (to remove old roots) and then cropped with sudan grass [Sorghum drummondii (Steud.) Millsp. \& Chas] for 2 years after removal of the old orchard before planting the experiment. The plot was laid out perpendicular to the old orchard rows, thus, giving a balanced effect of the location of the old trees on each rootstock and system. The trees were trickle irrigated as needed during the growing season using the Cornell Apple Irrigation Model based on a modified Penman-Monteith equation (NEWA.org) (Robinson et al., 2017) and received from 200 to $1000 \mathrm{~mm}$ of water depending on the year. Average annual precipitation for Peru, $\mathrm{NY}$, is $812 \mathrm{~mm}$. The trial was managed with conventional pesticides and fertilizers according to industry standards.

Tree management. All of the trees had three to five feathers (lateral branches produced the previous year) at planting. CL system was supported by a steel conduit pipe ( $3 \mathrm{~m}$ with $0.6 \mathrm{~m}$ in the ground) at each tree. SP, VA, and SA trees were supported by a single-wire trellis $(2.3 \mathrm{~m})$ connected to a steel conduit pipe ( $3 \mathrm{~m}$ with $15 \mathrm{~cm}$ in the ground) at each tree (Robinson and Hoying, 1999). TS systems were supported by a 3wire trellis $(2.5 \mathrm{~m})$.

CL trees were developed by initially heading each tree at $70 \mathrm{~cm}$ and thereafter annually heading the leader and lower tier scaffolds by one-third each year to produce a strong sturdy trunk and branch framework with permanent branches. Two permanent tiers of scaffold branches were developed, spaced $1 \mathrm{~m}$ apart, with four to five branches per tier. Limb spreading was carried out in years 3 and 5 using wooden limb spreaders. Scaffold branches between the first and second tiers were removed between the years 5 and 6 . Tree height was limited to $5 \mathrm{~m}$.

SP and VA trees were developed by heading the leader at $120 \mathrm{~cm}$ above the graft union at planting and shortening each feather by one-third their length. In years 2 through 6 , leaders were not headed. In year 3 , four to five lower scaffold branches were tied down to horizontal. Beginning in year 4, large diameter limbs $(>5 \mathrm{~cm})$ were removed back to the trunk with an angled cut to develop replacement limbs. Each year, two to three large branches were removed. Tree height was limited to $4 \mathrm{~m}$. With the VA, lateral branches were kept simple by removing sublateral branches to create a single axis for each branch. With the SP, sublateral branches were allowed to remain but were removed if they became as large as the main axis of the lateral branch.

SA trees were developed by heading the leader at $120 \mathrm{~cm}$ above the graft union at planting, removing one to three of the largest feathers, and leaving the remaining feathers unpruned. In years 2 through 4, the leaders were not headed. Beginning year 4 and continuing in years 6 and 8 , scaffold branches longer than $1 \mathrm{~m}$ and originating above $120 \mathrm{~cm}$ height on the trunk were tied down below horizontal $\left(\approx 120^{\circ}\right.$ from vertical), and one to two scaffold branches originating below 120 $\mathrm{cm}$ on the trunk were removed each year until no branches were left below $120 \mathrm{~cm}$. Tree height was limited to $4 \mathrm{~m}$ by bending the top of the tree horizontal at $4 \mathrm{~m}$ height in year 8 . Sublateral branches on the lateral branches were allowed to develop producing a highly branched scaffold with "fingers."

TS trees were developed by heading the leader at $150 \mathrm{~cm}$ above the graft union at planting, removing one to two of the largest feathers, and leaving the remaining feathers unpruned. In years 2 through 4, the leaders were left unheaded. Beginning in year 3, large-diameter limbs $(>2 \mathrm{~cm})$ were removed back to the trunk with an angled cut to develop replacement limbs. Each year one to two branches larger than $2 \mathrm{~cm}$ were removed. Tree height was limited to $3.5 \mathrm{~m}$. Only small lateral branches $(<2 \mathrm{~cm})$ were allowed to remain in the tree and they were each kept simple by removing sublateral branches to create a single axis for each branch.

Agronomic assessments. Yield (kg) and fruit number were recorded annually from each tree, and fruit size was then calculated using measured data (Marini et al., 2006). Trunk circumference $(\mathrm{cm})$ at $30 \mathrm{~cm}$ above graft union was measured at the end of the trial (2016) (Reig et al., 2018). Trunk crosssectional area (TCSA, $\mathrm{cm}^{2}$ ), cumulative yield efficiency $\left(\mathrm{kg} \cdot \mathrm{cm}^{-2}\right)$, and crop load (fruit number $/ \mathrm{cm}^{2}$ ) were then calculated (Marini et al., 2006). Absolute value for biennial bearing index (BBI) was calculated as follows:

$$
\mathrm{BBI}=\frac{(\text { yield year } n)-(\text { yield year } n+1)}{(\text { yield year } n)+(\text { yield year } n+1)},
$$

where 0 indicates no alternate bearing and 1 complete alternate bearing. Annual BBI was calculated for each year and the average of all years calculated. From 2007 onward, an 18$\mathrm{kg}$ fruit sample from each subplot was collected for fruit quality assessment. Fruit color, as a percentage of skin surface colored red (according to USDA color standards) was measured with an electronic weight size/ color sorter (MAF Industries, Travers, CA). Flesh firmness (Fruit Texture Analyzer; QA Supplies LLC, Norfolk, VA) and soluble solids content (Atago USA, Inc., Bellevue, WA) were also assessed (Torres et al., 2017). Fruit were harvested in two picks at commercial maturity when red color was at least $50 \%$ and a starch index of 5 for 'McIntosh' and 7 for 'Honeycrisp' using the Cornell generic starch chart (scale 1-9). All the systems and rootstocks were harvested on the same date. Cumulative yield was then calculated, whereas fruit quality was assessed at the main harvest date, usually the first pick.

Statistical analysis. Response variables were modeled using linear mixed effect models. Mixed models including each combination of cultivar $\times$ training system $\times$ rootstock as fixed factors and block as a random factor were built to compare treatment effects between cultivars. Mixed models including each combination of training system $x$ rootstock as fixed factor and block as a random factor were built to separate treatment effects for TCSA, average fruit size, cumulative yield, cumulative yield efficiency, cumulative crop load, and BBI for each cultivar. Crop load was included as a covariate to adjust fruit size. Mixed models including each combination of training system $\times$ rootstock as fixed factor, and block nested to year as a random factor were built to separate treatment effects for firmness, soluble solids, and color for each cultivar. Analyses for the systems (SA, VA, and TS) that had the same common rootstocks ('B.9', 'G.16', and 'M.9') were also performed. Therefore, mixed models including system or rootstock as fixed factor, and block nested to system or rootstock as a random factor were built to separate treatment effects for TCA, average fruit size, cumulative yield, cumulative yield efficiency, cumulative crop load, and BBI for each cultivar. Crop load was included as a covariate to adjust fruit size. Mixed models including each combination of system or rootstock as a fixed factor 
and block nested to system or rootstock and year as random factors were built to separate the treatment effects for firmness, soluble solids, and color for each cultivar. A mixed model including each combination of training system $\times$ rootstock, year, and training system $\times$ rootstock $\times$ year as fixed factors, and block as a random factor was built to separate the treatment effects for yield for each cultivar. Data were square root transformed to normalize data distribution. All mean separations were made by Tukey's honestly significant difference $(P=0.05)$. Residual analysis was performed to insure that model assumptions were met. Data were analyzed using the JMP statistical software package (Version 12; SAS Institute, Inc., Cary, NC).

\section{Results}

Tree size. Larger trees were observed with 'McIntosh' compared with 'Honeycrisp' (Table 2). For both cultivars, the biggest trees of the trial were with CL systems on 'M.M.111', which were $200 \%$ to $300 \%$ larger than the rest of the treatments averaged. With 'Honeycrisp', SP with 'G.30' trees were largest $\left(70 \mathrm{~cm}^{2}\right)$, whereas the smallest (29 $\mathrm{cm}^{2}$ ) ones were with SA with 'B.9', and TS with 'B.9' and 'M.9'. With 'McIntosh', SP with 'G.30' trees were also the second largest

Table 1. Spacing, tree planting density, training system, and rootstock evaluated at Peru, Clinton County, NY, 2002-16

\begin{tabular}{lcll}
\hline Spacing $(\mathrm{m})$ & Planting density (trees/ha) & \multicolumn{1}{c}{ Training system } & \multicolumn{1}{c}{ Rootstock } \\
\hline $3.05 \times 6.08$ & 539 & Central Leader (CL) & M.M.111 \\
$2.13 \times 4.28$ & 1,097 & Slender Pyramid (SP) & G.30 \\
& 1,794 & M.26 & B.9 \\
$1.52 \times 3.67$ & & & G.16 \\
& & Vertical Axis (VA) & M.9 (Nic $\left.{ }^{\circledR} 29\right)$ \\
& & & B.9 9 \\
& & & G.16 \\
& \multirow{2}{*}{3,230} & Tall Spindle (TS) & M.9 (Nic $\left.{ }^{\circledR} 29\right)$ \\
& & & B.9 \\
& & & G.16 \\
& & & M.9 (Nic $\left.{ }^{\circledR} 29\right)$ \\
\hline
\end{tabular}

trees $\left(105 \mathrm{~cm}^{2}\right)$, whereas all the systems that had 'B.9' and 'M.9' rootstocks were the smallest $\left(40-56 \mathrm{~cm}^{2}\right)$.

When comparing within systems that had common rootstocks, the smallest trees were with TS whereas there was no difference between SA and VA. Among rootstocks common across the three systems, 'G.16' was bigger than 'B.9' and 'M.9' for both cultivars (Table 2).

Yield and fruit size. Yield was higher for 'McIntosh' compared with 'Honeycrisp' (Table 2; Fig. 1). For 'Honeycrisp', the highest yields were observed for TS with 'B.9' and SP with 'G.30'; however, significant differences were only observed for SP with 'M.26' and CL with 'M.M.111', which had the lowest yields of the trial. For 'McIntosh', the highest yield was observed for TS with 'M.9' (680 t.ha' $\left.{ }^{-1}\right)$ and 'B.9' (608 t.ha $\left.{ }^{-1}\right)$. The lowest yields were for CL $\left(284 \mathrm{t} \cdot \mathrm{ha}^{-1}\right)$ and SP $\left(\approx 364 \mathrm{t} \cdot \mathrm{ha}^{-1}\right)$.

When comparing within systems with common rootstocks, VA and TS had the greatest yields with 'Honeycrisp' (306$341 \mathrm{t} \cdot \mathrm{ha}^{-1}$ ), and there were no significant differences among the three rootstocks in common across systems (Table 2). With 'McIntosh', higher yields were observed for TS $\left(593 \mathrm{t} \cdot \mathrm{ha}^{-1}\right)$ compared with VA and SA $\left(\approx 475 \mathrm{t} \cdot \mathrm{ha}^{-1}\right)$, whereas among rootstocks, 'M.9' had the greatest yields (586 t.ha ${ }^{-1}$ ), followed by 'B.9' $\left(511 \mathrm{t} \cdot \mathrm{ha}^{-1}\right)$, and finally

Table 2. Final trunk cross sectional area $\left(\mathrm{TCA}, \mathrm{cm}^{2}\right)$, cumulative yield $\left(\mathrm{t} \cdot \mathrm{ha} \mathrm{a}^{-1}\right)$, average fruit size $(\mathrm{g})$, cumulative yield efficiency $\left(\mathrm{kg} \cdot \mathrm{cm}^{-2} \mathrm{TCA}\right)$, cumulative crop load (fruit number $/ \mathrm{cm}^{2} \mathrm{TCA}$ ), and biennial bearing index for each combination of training system (Central Leader - CL, SolAxe-SA, Slender Pyramid - SP, Tall Spindle-TS, and Vertical Axis-VA) and rootstock ('M.M.111', 'B.9', 'G.16', 'M.9', 'G.30', and 'M.26') for 'Honeycrisp' and 'McIntosh' at Peru, Clinton County, NY over 15 years (2002-16). Yield data from 2017 (spring frost) was not used to estimate the biennial bearing index. Means followed by different letters denotes significant differences (Tukey's honestly significant difference, $P \leq 0.05$ ). $<0.0001-\mathrm{H}$ or $<0.0001$-M, significant with higher values for 'Honeycrisp' or 'McIntosh', respectively. Gray bars represent variable value.

\begin{tabular}{|c|c|c|c|c|c|c|c|}
\hline System an & d rootstock & Final TCA $(\mathrm{cm} 2)$ & $\begin{array}{l}\text { Cumulative yield } \\
\text { (t/ha) }\end{array}$ & $\begin{array}{l}\text { Average fruit size } \\
(\mathrm{g})\end{array}$ & $\begin{array}{l}\text { Cumulative yield } \\
\text { efficiency }(\mathrm{kg} / \mathrm{cm} 2)\end{array}$ & $\begin{array}{l}\text { Average crop load } \\
\text { (fruit \#/TCA) }\end{array}$ & $\begin{array}{c}\text { Biennial bearing } \\
\text { index }\end{array}$ \\
\hline \multirow[t]{20}{*}{ Honeycrisp } & CL MM111 & $146 \mathrm{~A}$ & i $177 \mathrm{C}$ & i $229 \mathrm{AB}$ & $2.3 \mathrm{~F}$ & $10 \mathrm{G}$ & $0.27 \mathrm{~A}$ \\
\hline & SP G30 & $70 \mathrm{~B}$ & $354 \mathrm{~A}$ & $235 \mathrm{~A}$ & $4.6 \mathrm{AB}$ & $21 \mathrm{ABCD}$ & $0.24 \mathrm{AB}$ \\
\hline & SP M26 & $61 \mathrm{BC}$ & 207 BC & $212 \mathrm{C}$ & 3.2 CDEF & 15 CDEFG & $0.20 \mathrm{ABCD}$ \\
\hline & SA B9 & $34 \mathrm{C}$ & $288 \mathrm{ABC}$ & 229 ABC & $4.7 \mathrm{AB}$ & $22 \mathrm{AB}$ & 0.16 BCD \\
\hline & SA G16 & $46 \mathrm{BC}$ & $263 \mathrm{ABC}$ & $225 \mathrm{ABC}$ & 3.2 CDEF & 15 DEFG & $0.22 \mathrm{ABC}$ \\
\hline & SAM9 & $36 \mathrm{BC}$ & $270 \mathrm{ABC}$ & $217 \mathrm{BC}$ & $4.2 \mathrm{ABC}$ & $20 \mathrm{ABCD}$ & $0.15 \mathrm{CD}$ \\
\hline & VA B9 & $35 \mathrm{BC}$ & $321 \mathrm{AB}$ & $228 \mathrm{ABC}$ & $5.1 \mathrm{~A}$ & $24 \mathrm{~A}$ & $0.15 \mathrm{CD}$ \\
\hline & VA G16 & $48 \mathrm{BC}$ & $252 A B C$ & $215 \mathrm{BC}$ & 2.9 DEF & 14 EFG & $0.17 \mathrm{BCD}$ \\
\hline & VA M9 & $46 \mathrm{BC}$ & $345 \mathrm{AB}$ & $218 \mathrm{BC}$ & $4.3 \mathrm{ABC}$ & $21 \mathrm{ABC}$ & $0.16 \mathrm{CD}$ \\
\hline & TS B9 & $29 \mathrm{C}$ & $366 \mathrm{~A}$ & $220 \mathrm{BC}$ & $3.9 \mathrm{BCD}$ & $18 \mathrm{ABCDE}$ & $0.13 \mathrm{D}$ \\
\hline & TS G16 & $39 \mathrm{BC}$ & $320 \mathrm{AB}$ & $217 \mathrm{ABC}$ & $2.5 \mathrm{EF}$ & 12 FG & $0.17 \mathrm{BCD}$ \\
\hline & TS M9 & $29 \mathrm{C}$ & 338 AB & 214 BC & $3.7 \mathrm{BCDE}$ & 17 BCDEF & $0.12 \mathrm{D}$ \\
\hline & $P$ & $3 \bar{A} \bar{A} \bar{B}-$ & -0.0009 & $<-0001$ & & $---7_{-} \leq 0001$ & $--0_{0}<001$ \\
\hline & & $\begin{array}{l}39 \mathrm{AB} \\
43 \mathrm{~A}\end{array}$ & $\begin{array}{l}274 \mathrm{~B} \\
306 \mathrm{AB}\end{array}$ & 223 & $4.0 \mathrm{~A}$ & $: \begin{array}{l}19 \mathrm{~A} \\
19 \mathrm{~A}\end{array}$ & $\begin{array}{l}0.18 \mathrm{~A} \\
0.16 \mathrm{AB}\end{array}$ \\
\hline & $\begin{array}{l}\text { VA } \\
\text { TS }\end{array}$ & $\begin{array}{l}43 \mathrm{~A} \\
32 \mathrm{~B}\end{array}$ & $\begin{array}{l}306 \mathrm{AB} \\
341 \mathrm{~A}\end{array}$ & $\begin{array}{l}219 \\
218\end{array}$ & $\begin{array}{l}4.1 \mathrm{~A} \\
3.4 \mathrm{~B}\end{array}$ & $i$ & $\begin{array}{l}0.16 \mathrm{AB} \\
0.14 \mathrm{~B}\end{array}$ \\
\hline & TS & 0.0060 & $\begin{array}{l}! 341 \mathrm{~A} \\
0.0405\end{array}$ & $\begin{array}{l}218 \\
\text { NS }\end{array}$ & 0.0019 & 0.0041 & $\begin{array}{l}0.14 \mathrm{~B} \\
0.0237\end{array}$ \\
\hline & B9 & $33 \mathrm{~B}$ & 325 & 223 A & $4.6 \mathrm{~A}$ & $21 \mathrm{~A}$ & $0.15 \mathrm{~B}$ \\
\hline & G16 & $45 \mathrm{~A}$ & 278 & $221 A B$ & $2.9 \mathrm{C}$ & $14 \mathrm{C}$ & $0.19 \mathrm{~A}$ \\
\hline & M9 & : $37 \mathrm{~B}$ & 318 & 215 B & $4.1 \mathrm{~B}$ & $19 \mathrm{~B}$ & $0.15 \mathrm{~B}$ \\
\hline & $P$ & 0.0039 & NS & 0.0033 & $<.0001$ & $<.0001$ & 0.0049 \\
\hline System $\times$ rootstock & $P$ & NS & NS & NS & NS & NS & NS \\
\hline \multirow[t]{20}{*}{ Mclntosh } & CL MM111 & $265 \mathrm{~A}$ & $284 \mathrm{~F}$ & $159 \mathrm{~A}$ & $2.1 \mathrm{E}$ & $13 \mathrm{E}$ & $0.26 \mathrm{~A}$ \\
\hline & SP G30 & $104 \mathrm{~B}$ & 387 DEF & $143 \mathrm{~B}$ & $3.5 \mathrm{BCDE}$ & $25 \mathrm{CDE}$ & $0.12 \mathrm{BC}$ \\
\hline & SP M26 & $78 \mathrm{BCD}$ & $341 \mathrm{EF}$ & $147 \mathrm{AB}$ & 4.3 $\mathrm{ABCD}$ & $31 \mathrm{ABCD}$ & $0.16 \mathrm{~B}$ \\
\hline & SA B9 & $45 \mathrm{D}$ & $483 \mathrm{BCD}$ & $142 A B$ & $6.0 \mathrm{~A}$ & $45 \mathrm{~A}$ & $0.12 \mathrm{BC}$ \\
\hline & SA G16 & $73 \mathrm{BCD}$ & $431 \mathrm{CDE}$ & $138 \mathrm{~B}$ & $3.3 \mathrm{CDE}$ & $25 \mathrm{BCDE}$ & $0.15 \mathrm{~B}$ \\
\hline & SA M9 & $51 \mathrm{D}$ & 526 BC & $143 \mathrm{AB}$ & $5.8 \mathrm{~A}$ & $43 \mathrm{~A}$ & $0.11 \mathrm{BC}$ \\
\hline & VA B9 & $45 \mathrm{D}$ & $442 \mathrm{CDE}$ & $141 \mathrm{AB}$ & $5.5 \mathrm{ABC}$ & $41 \mathrm{AB}$ & $0.12 \mathrm{BC}$ \\
\hline & VA G16 & $98 \mathrm{BC}$ & $430 \mathrm{CDE}$ & 142 B & $2.4 \mathrm{DE}$ & $18 \mathrm{DE}$ & $0.13 \mathrm{BC}$ \\
\hline & VA M9 & $56 \mathrm{CD}$ & $552 \mathrm{ABC}$ & $140 \mathrm{AB}$ & $5.6 \mathrm{AB}$ & $42 A B$ & $0.10 \mathrm{BC}$ \\
\hline & TS B9 & $34 \mathrm{D}$ & $608 \mathrm{AB}$ & $139 \mathrm{AB}$ & $5.6 \mathrm{AB}$ & $42 \mathrm{~A}$ & $0.08 \mathrm{C}$ \\
\hline & TS G16 & $58 \mathrm{CD}$ & $491 \mathrm{BCD}$ & $139 \mathrm{~B}$ & $2.7 \mathrm{DE}$ & $20 \mathrm{DE}$ & $0.10 \mathrm{BC}$ \\
\hline & TS M9 & $40 \mathrm{D}$ & 680 A & 139 AB & $5.3 \mathrm{ABC}$ & $40 \mathrm{ABC}$ & $0.09 \mathrm{BC}$ \\
\hline & $\ldots$ & $5 \overline{6}-\bar{A}$ & $480^{-} \mathrm{B}$ & 140 & -5.0 & 38 & $-0.13 \bar{A}^{-}$ \\
\hline & VA & $66 \mathrm{~A}$ & $475 \mathrm{~B}$ & 141 & 4.5 & $i$ & $0.12 \mathrm{AB}$ \\
\hline & & : $44 \mathrm{~B}$ & $593 \mathrm{~A}$ & 139 & 4.5 & ! & 0.09 В \\
\hline & $P$ & 0.0002 & 0.0002 & NS & NS & NS & 0.0072 \\
\hline & B9 & $41 \mathrm{~B}$ & $511 \mathrm{~B}$ & 140 & $5.7 \mathrm{~A}$ & $43 \mathrm{~A}$ & $0.11 \mathrm{AB}$ \\
\hline & G16 & $76 \mathrm{~A}$ & : $451 \mathrm{C}$ & 140 & $2.8 \mathrm{~B}$ & $21 \mathrm{~B}$ & $0.13 \mathrm{~A}$ \\
\hline & M9 & 49 B & $586 \mathrm{~A}$ & 140 & $5.6 \mathrm{~A}$ & $42 \mathrm{~A}$ & $0.10 \mathrm{~B}$ \\
\hline & $P$ & $<.0001$ & $<.0001$ & NS & $<.0001$ & $<.0001$ & 0.0464 \\
\hline \multirow{2}{*}{ System $\times$ rootstock } & $P$ & 0.0050 & NS & NS & NS & NS & NS \\
\hline & $P$ & $<.0001-\mathrm{M}$ & $<.0001-\mathrm{M}$ & $<.0001-\mathrm{H}$ & $<.0001-\mathrm{M}$ & $<.0001-\mathrm{M}$ & $<.0001-\mathrm{H}$ \\
\hline
\end{tabular}




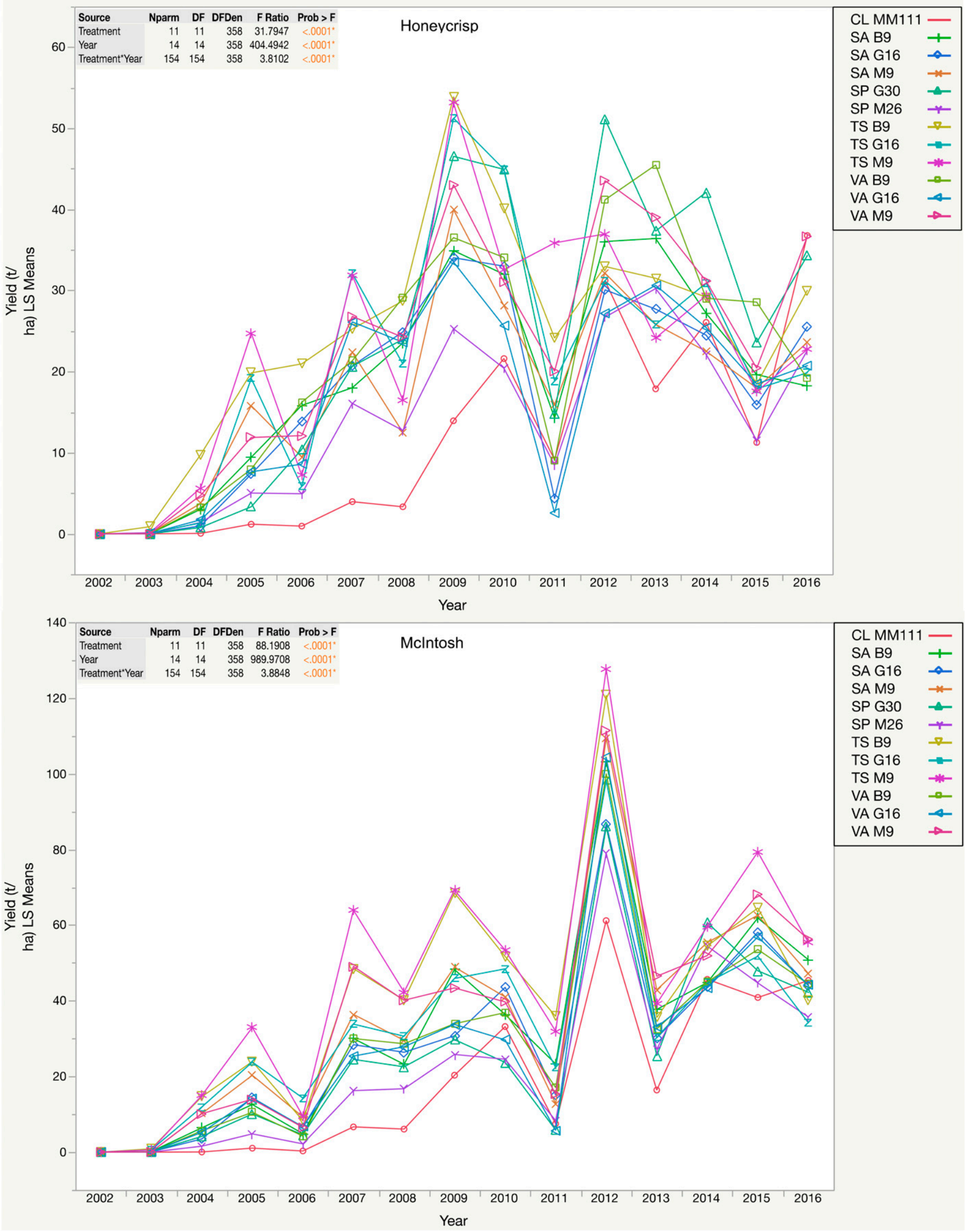

Fig. 1. Annual yields $\left(\mathrm{t} \cdot \mathrm{ha}^{-1}\right)$ for each combination of training system (Central Leader - CL, SolAxe — SA, Slender Pyramid — SP, Tall Spindle—TS, and Vertical Axis-VA) and rootstock ('M.M.111', 'B.9', 'G.16', 'M.9', 'G.30', and 'M.26') for 'Honeycrisp' and 'McIntosh' at Peru, Clinton County, NY, $2002-16$. 

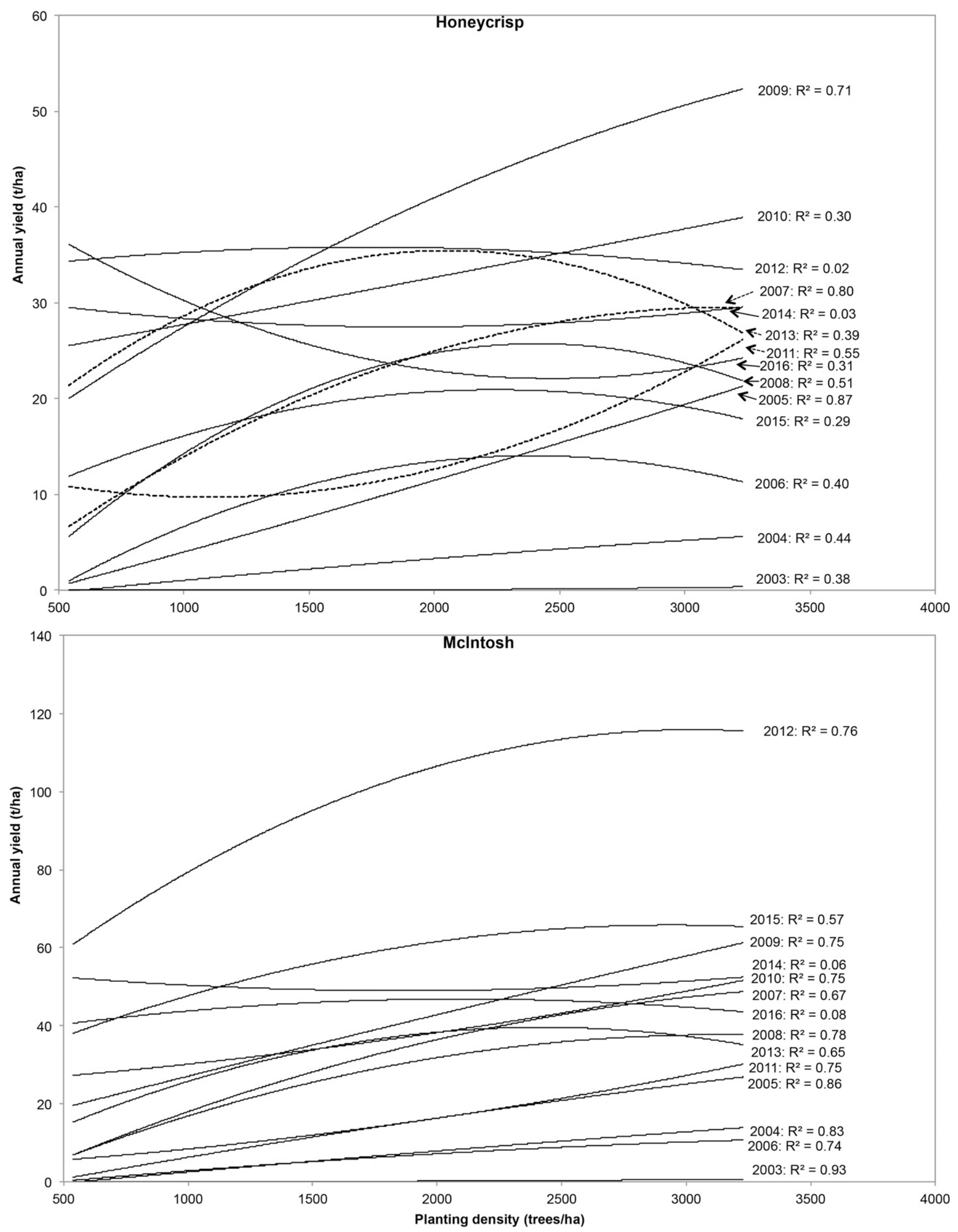

Fig. 2. Regressions for annual yield (t.ha ${ }^{-1}$ ) to tree density (trees/ha) for each cultivar (Honeycrisp and McIntosh) at Peru, Clinton County, NY, $2002-16$. 

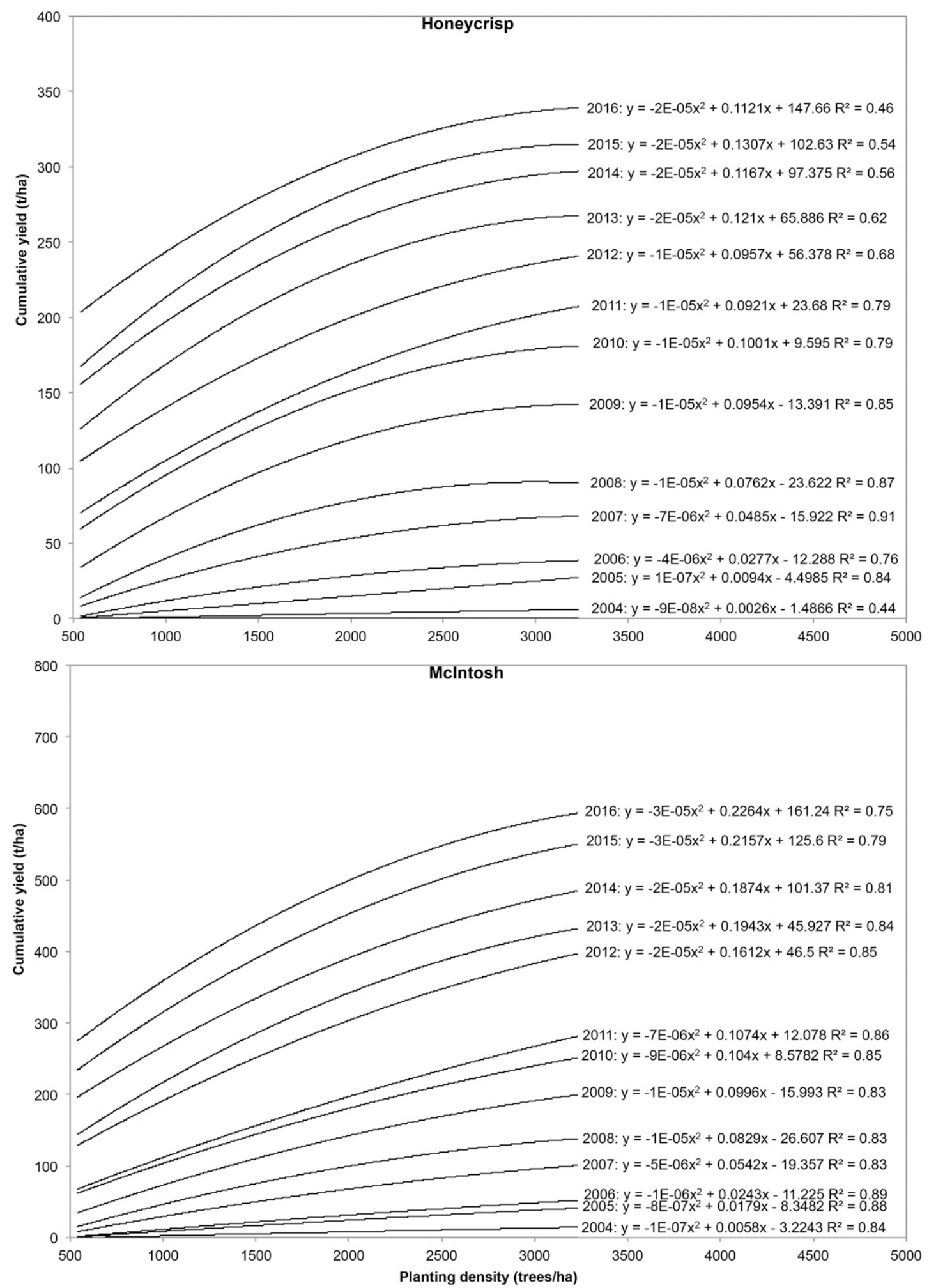

Fig. 3. Regressions for annual cumulative yield $\left(\mathrm{t} \cdot \mathrm{ha}^{-1}\right)$ to tree density (trees/ha) for each cultivar (Honeycrisp and McIntosh) at Peru, Clinton County, NY, 2002-16.

'G.16' had the lowest cumulative yield (451 $\mathrm{t} \cdot \mathrm{ha}^{-1}$ ) among the three rootstocks.

Yield was reduced in 2011 because of a spring frost, leading to the highest annual yields the following year (2012) (Fig. 1). The very large crop in 2012 affected return bloom in 2013, especially for 'McIntosh', reducing the yield down to the level of the frost affected year (2011).

HortScience Vol. 53(7) July 2018
The relationship between annual yield and tree planting density was explored. In the early years (2-5) the relationship was nearly linear (Figs. 2 and 3). For 'McIntosh' the relationship in years 5-10 also had a strong linear tendency but with a slight quadratic shape, where the highest planting density had the highest annual yield. However, as the orchard aged, the shapes of the annual yield curves could be flat, negative, or quadratic positive depending on years. This was especially true for 'Honeycrisp', where biennial bearing would create situations where the high-density system would have a low-crop year, whereas the low-density system would have a high-crop year. For 'McIntosh' in most years after the first 5 years, the relationship had a strong quadratic 
shape with a maximum yield in the mid densities.

A similar trend for each cultivar was observed when studying the relationship of cumulative yield to tree density for the entire 15 years (Fig. 3). Cumulative yield was highly correlated to planting density, with higher $R^{2}$ values for 'McIntosh' than for 'Honeycrisp'. Cumulative yield of 'McIntosh' after 15 years was double when planting density was 3230 trees/ha compared with 500 trees/ha. For 'Honeycrisp' cumulative yield was increased 1.75 times when planted at the highest density compared with the lowest (539 trees/ha). The doubling of annual yield at the highest density compared with the lowest density was less apparent in later years than at the early orchard stage. For 'Honeycrisp', there was a substantial increase in cumulative yield in 2009 and 2012 due to strong biennial bearing (low crops in 2008 and 2011), whereas for 'McIntosh' a large increase in yield was observed in 2012 due to a spring frost in 2011, which damaged 'McIntosh' flowers.

Larger fruit sizes were observed for 'Honeycrisp' (222 g on average), compared with 'McIntosh' (141 g) (Table 2). There were few significant differences among treatments in fruit size, especially for 'McIntosh'. For 'Honeycrisp', fruit size was smaller for SP on 'M.26'. Among rootstocks, there were larger fruit of 'Honeycrisp' on 'M.9' compared with 'B.9' (215 vs. 223 g, respectively) (Table 2).

Yield efficiency, crop load, and biennial bearing. 'Honeycrisp' yield efficiency was the highest for VA and SA with 'B.9' and 'M.9', and for SP with 'G.30' (Table 2). The lowest values were for CL with 'M.M.111' and TS with 'G.16'. Similarly for 'McIntosh', the highest yield efficiencies were for SA, VA, and TS with 'B.9' and 'M.9', and the lowest values were with 'G.16' and 'M.M.111'.

For 'Honeycrisp' within systems with common rootstocks, yield efficiency was higher for SA and VA compared with TS ( $\approx 4$ vs. $3.4 \mathrm{~kg} \cdot \mathrm{cm}^{-2}$, respectively), whereas among rootstocks across all systems, 'B.9' had the highest value, followed by 'M.9', and then 'G.16' (Table 2). For 'McIntosh', there were no differences among systems, whereas 'M.9' and 'B.9' had similar yield efficiencies, which were significantly higher than ' $\mathrm{G} .16$ ' ( $\approx 5.6 \mathrm{vs} .2 .8 \mathrm{~kg} \cdot \mathrm{cm}^{-2}$, respectively).

'Honeycrisp' average crop load was higher for VA with 'B.9', followed by SA with 'B.9', VA with 'M.9', and SP with 'G.30' (Table 2). The lowest values were observed for CL with 'M.M.111', VA with 'G.16', and TS with 'G.16'. For 'McIntosh', the SA, VA, and TS with 'B.9' and 'M.9' had the highest crop loads and 'G.16', 'G.30', and 'M.M.111' the lowest.

TS had a lower crop load than SA and VA for 'Honeycrisp', whereas among rootstocks crop load were the highest for 'B.9', followed by 'M.9' and then 'G.16' (Table 2). No differences among systems (TS, SA, and VA) with common rootstocks were observed for 'McIntosh', whereas among rootstocks
'G.16' had lower crop load values than 'M.9' and 'B.9'.

Biennial bearing was more apparent on 'Honeycrisp' than on 'McIntosh' (Table 2). For 'Honeycrisp', biennial bearing decreased with increasing planting density, TS (3230 trees/ha) had the lowest BBI, followed by VA and SA (1794 trees/ha), SP (1097 trees/ha), and CL (539 trees/ha) the highest. Among rootstocks common to the same systems (TS, SA, and VA), 'G.16' induced higher biennial bearing than 'B.9' or 'M.9' ( 0.19 vs. 0.15 , respectively).

For 'McIntosh', differences in biennial bearing were less clear, although the highest values were still for $\mathrm{CL}$, and tended to decrease with increasing planting density. Biennial bearing was lower for TS (0.09) compared with SA (0.13), and lower on 'M.9' (0.1) than 'G.16' (0.13) (Table 2).

Fruit quality. There were no significant differences in fruit firmness or soluble solids for 'Honeycrisp' (Table 3). When comparing rootstocks ('M.9', 'B.9', and 'G.16') common to the same three systems (TS, SA, and VA), fruit from 'G.16' trees had a slightly higher firmness compared with 'B.9' fruit (6.2 vs. $6 \mathrm{~kg}$, respectively). Fruit red color was highest $(52 \%)$ from $\mathrm{CL}$ trees with 'M.M.111' and TS with 'G.16', and lowest $(42 \%)$ from SA and VA trees with 'B.9'. When comparing systems with common rootstocks, TS had higher $(47 \%)$ color than either SA (44\%) or VA (45\%). Color was best from trees grafted on 'G.16' (49\%), followed by 'M.9' $(45 \%)$, and poorest on 'B.9' $(43 \%)$.

For 'McIntosh', few differences in fruit quality among treatments were observed (Table 3). Lower overall values for both fruit firmness and SS were observed for CL with 'M.M.111', whereas higher values were measured on ' $\mathrm{G} .16$ '. Color was higher ( $64 \%$ and $60 \%$ ) for SA with 'G.16' and VA with 'G.16', and lowest (45\%) for CL with 'M.M.111'. When comparing systems with common rootstocks, color was the best for SA $(61 \%)$, followed by VA (55\%), and TS (52\%). The highest values were observed on 'G.16' (59\%), followed by 'M.9' (56\%), then 'B.9' (54\%).

\section{Discussion}

Tree size. In our trial, 'Honeycrisp' trees were smaller than 'McIntosh'. Greene and Weis (2001) observed a weak growing habit of 'Honeycrisp' in New England, whereas 'McIntosh' has been described as a moderately vigorous cultivar (Ferree and Warrington, 2003), supporting the differences in tree size that we observed.

The biggest trees in this trial were 'McIntosh' on 'M.M.111' and 'G.30'. Both rootstocks have been reported to be more vigorous than 'M.9' and 'B.9' in previous studies (Robinson et al., 2003, 2011b; Russo et al., 2007). 'G.16' was significantly more vigorous than 'M.9' and 'B.9' within the same training systems for both 'Honeycrisp' and 'McIntosh'. 'G.16' tree size has been previously reported to be similar to 'M.9' size with 'Jonagold' but slightly more vigorous with 'Gala' (Robinson et al., 2003), confirming the importance of testing rootstock performance for each particular cultivar. Training system and planting density also affected tree vigor. The smallest trees were on TS (3230 trees/ha) or SA and VA (1794 trees/ha). This agrees with previous studies (Lordan et al., 2018a; Robinson, 2008b), which found the highest density plantings had smaller trees. This was likely because of the limb removal pruning to contain trees in a smaller planting space of the TS system that has a dwarfing effect (Robinson, 2007). The dwarfing associated with the highdensity TS system could also have been partially due to greater root competition for water and nutrients, and greater partitioning of carbon into fruit.

Yield, fruit size, yield efficiency, crop load, and biennial bearing. Our study showed higher yields of 'Honeycrisp' on 'M.9' and 'B.9' rootstocks vs. 'G.16' when trained on TS, VA, or SA in high planting densities (1794-3230 trees/ha). However, 'B.9' performance with 'McIntosh' was inferior to 'M.9'. In previous studies, for different soil types and climatic conditions, 'B.9' has been reported to produce lower yield than 'M.9' (Autio et al., 2013; Bonany et al., 2004; Lordan et al., 2016; Marini et al., 2006; Robinson et al., 2003). Its high performance with 'Honeycrisp' in our study could be indicative of its relatively low biennial bearing index in our study, its adaptation to the cold winters and cool growing climate of northern New York State or both. Although 'B.9' had similar tree growth as 'M.9' with 'McIntosh', its yield was inferior to that of 'M.9', indicating a better adaptability of 'M.9' with 'McIntosh'. The lowest planting density (CL/'M.M.111', 539 trees/ha) had the lowest yields, followed by SP ('G.30' and 'M.26', 1097 trees/ha). Similar to tree size, yield was related to rootstock and planting density. 'G.30' and 'M.26', have also been reported to give less yield than 'M.9' in previous studies (Autio et al., 2013; Lordan et al., 2016; Marini et al., 2006; Robinson et al., 2003). Although 'M.26' has relatively good winterhardiness (Robinson et al., 2003), its poor performance in our study could have been due to replant disease susceptibility (Kviklys et al., 2016) and to less than optimum planting density.

Cumulative yield was highly correlated with planting density in our study. For both cultivars, the highest cumulative yields were observed at 3230 trees/ha. Greater differences among planting densities were observed for 'McIntosh' than 'Honeycrisp'. An interesting exception to the relationship of planting density and cumulative yield was with 'Honeycrisp' on 'G.30' rootstock. This combination had essentially the same yield as the best performing system of TS on 'B.9' but with much lower planting density. This may indicate a good match between scion productivity and tree architecture, which produced sufficient fruit-filled canopy. In addition, 'G.30' was suggested to have an excellent adaptation to cold winters and cool 
Table 3. Average flesh firmness ( $\mathrm{kg}$ ), soluble solids ( ${ }^{\circ}$ Brix), and color $(\%)$ at harvest for each combination of training system (Central Leader-CL, SolAxe-SA, Slender Pyramid - SP, Tall Spindle—TS, and Vertical Axis-VA) and rootstock ('M.M.111', 'B.9', 'G.16', 'M.9', 'G.30', and 'M.26') for 'Honeycrisp' and 'McIntosh' at Peru, Clinton County, NY over 15 years (2002-16). Means followed by different letters denotes significant differences (Tukey's honestly significant difference, $P \leq 0.05)$. $<0.0001-\mathrm{H}$ or $<0.0001-\mathrm{M}$, significant with higher values for 'Honeycrisp' or 'McIntosh', respectively. Gray bars represent variable value.

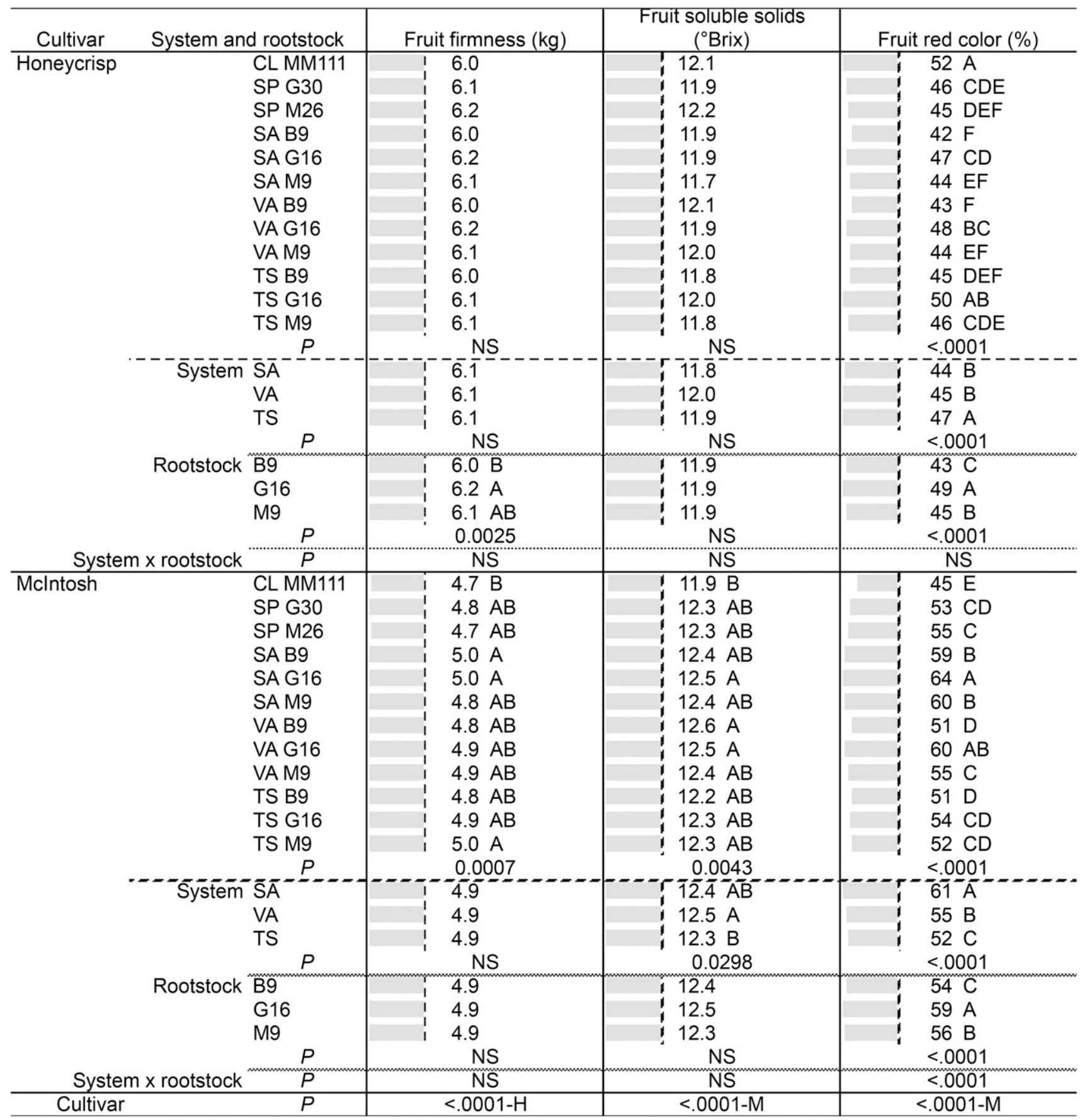

growing seasons (Robinson et al., 2003). Training systems planted at mid-densities (1794 trees/ha), such as VA and SA, with either 'B.9' or 'M.9' had the highest yield efficiencies and crop loads with a low-vigor cultivar such as Honeycrisp; even SP (1097 trees/ha) on 'G.30' had one of the highest yield efficiencies with that cultivar. On the other hand, for the moderate-vigor cultivar McIntosh, TS had similar yield efficiency as SA and VA with either 'B.9' or 'M.9', and higher cumulative yield. This is similar to previous observations (Lordan et al., 2018a) that after 20 years, 'McIntosh' had higher yields in high-density plantings (3500 trees/ ha). In the present study, average annual yield for 'McIntosh' was $41 \mathrm{t} \cdot \mathrm{ha}^{-1}$, whereas for 'Honeycrisp' it was 25 t.ha ${ }^{-1}$. These yields are lower than reported by other studies (Autio et al., 2011; Lordan et al., 2016; Robinson et al., 2011a). The shorter growing season in Northern New York, compared with other major apple-producing areas such as Washington State or western New York, plus harsh climatic conditions (very cold winters, late fall and spring frosts), might explain lower yields observed in the present study carried out in Peru, Clinton County, NY.

For both 'Honeycrisp' and 'McIntosh', biennial bearing was lower for TS with on either 'M.9' or 'B.9'. These observations coincide with our previous study with 'Honeycrisp' (Lordan et al., 2017b), where we found no significant differences between 'B.9' and 'M.9'. Furthermore, the more vigorous the trees were in our study, the higher the biennial bearing they had: for instance, TS had both the lowest vigor and biennial bearing. This suggests a better 
balance of vegetative growth and fruiting for trees on TS rather than with CL systems. As many authors suggest, equilibrium between fruiting and growth is key in reducing alternate bearing (Costes et al., 2006; Forshey and Elfving, 1989).

When comparing fruit size, no important effect of either training system or rootstock was observed for either cultivar. Only 'Honeycrisp' on SP with 'M.26' had smaller fruit. Other studies have observed no significant differences in fruit size between 'M.9' and 'M.26' for 'Honeycrisp' (Robinson et al., 2016; Russo et al., 2007), 'McIntosh' (Autio et al., 2011), or 'Gala' (Autio et al., 2013; Russo et al., 2007).

Fruit quality. Internal quality was only slightly affected by training system and rootstock, but red color was more affected depending on the training system and rootstock combination. Smaller trees with less vegetative growth, such as those on SA, VA, and TS, had the greater overall red color. This coincides with other studies reporting sunlight distribution within the canopy as the main factor affecting fruit color and fruit quality (Awad et al., 2001; Sinoquet et al., 2008). We also saw significant differences among rootstocks regarding fruit color; however, these differences were relatively small, $\approx 2 \%$ to $5 \%$ for 'Honeycrisp' and 'McIntosh', respectively (Table 3). Rootstock effect on fruit color appears to be related to rootstock vigor, affecting vegetative growth, and thus light distribution within the canopy. To counteract this, some authors have suggested summer pruning to improve fruit color (Palmer, 1999; Robinson et al., 1991).

\section{Conclusions}

In the cold climate of this study, both 'McIntosh' and 'Honeycrisp' performed well in high-density plantings. TS (3230 trees/ha) with 'M.9' was the combination that gave the highest cumulative yields with higher crop loads and yield efficiency indices, reduced biennial bearing and with no significant differences in fruit size and quality. However, with the weak-growing cultivar Honeycrisp, the largest fruit, and the highest yield efficiency and crop load were with 'B.9' instead of 'M.9', although cumulative was not different from 'M.9'. In addition, a middensity system such as SP (1097 trees/ha) with 'G.30' provided similar results as the high-density option. This may be due to the greater cold-hardiness of 'G.30' compared with 'M.9' or 'B.9'. Furthermore, although some growers may use 'M.26' (slightly more vigorous than 'M.9') for weak-growing cultivars such as Honeycrisp, others may use B.9 due to its higher tolerance to fire blight. However, as pointed out in this study, both 'M.26' and 'B.9' might be compromised in replant sites, especially where fumigation is not possible such as New York State. As this study has shown, 'G.30' which has some genetic tolerance of ARD could be a good option in these scenarios. The poorer performance of 'G.16' was unexpected. It has good winterhardiness but despite its good tree growth and survival it was not as productive as 'M.9' and 'B.9'. These results are specific to the cold climate in northern New York State. In climates that are warmer, the relatively easy of management of very highdensity systems such as the TS becomes more difficult because of greater vegetative vigor. In those climates, weaker growing rootstocks would be preferred.

To sum up, although TS on 'M.9' would be the best option for new orchards, TS on 'B.9' rather than 'M.9' might be the way to go when fire blight pressure is high. On the other hand, 'G.30' with SP (1097 trees/ha) might be the least risky option for weakgrowing cultivars that are planted in cold climates and short growing seasons, and when fumigation for ARD is not possible. Other newer Geneva ${ }^{\circledR}$ rootstocks that are not only similar in dwarfing as 'M.9', but also winterhardy and resistant to ARD and fire blight could be even a better option. However, these need long-term testing in cold climates.

Fruit price, labor (cost and availability), and other economical factors will also determine profitability of each combination of training system and rootstock. Therefore, economic studies should complement this kind of trial, since the agronomic and economic optimum combinations may not be the same.

\section{Literature Cited}

Autio, W., T. Robinson, D. Archbold, W. Cowgill, C. Hampson, R.P. Quezada, and D. Wolfe. 2013. 'Gala' apple trees on supporter 4, P.14, and different strains of B.9, M.9 and M.26 rootstocks: Final 10-year report on the 2002 NC-140 apple rootstock trial. J. Amer. Pomol. Soc. 67(2):62-71.

Autio, W.R., T.L. Robinson, B. Black, T. Bradshaw, J.A. Cline, R.M. Crassweller, C.G. Embree, E.E. Hoover, S.A. Hoying, K.A. Iungerman, R.S. Johnson, G. Lang, M.L. Parker, R.L. Perry, G.L. Reighard, J.R. Schupp, M. Stasiak, M. Warmund, and D. Wolfe. 2011. Performance of 'Fuji' and 'McIntosh' apple trees after 10 years as affected by several dwarf rootstocks in the 1999 NC-140 apple rootstock trial. J. Amer. Pomol. Soc. 65(2):2-20.

Awad, M.A., P.S. Wagenmakers, and A. de Jager. 2001. Effects of light on flavonoid and chlorogenic acid levels in the skin of 'Jonagold' apples. Scientia Hort. 88(4):289298.

Badiu, D., F.H. Arion, I.C. Muresan, R. Lile, and V. Mitre. 2015. Evaluation of economic efficiency of apple orchard investments. Sustainability 7(8):10521-10533.

Balkhoven-Baart, J., P. Wagenmakers, J. Bootsma, M. Groot, and S. Wertheim. 2000. Developments in Dutch apple plantings. Acta Hort. 513:261-270.

Bonany, J., J. Carbo, M. Casals, R. Montserrat, and I. Iglesias. 2004. Performance of some clonal apple rootstocks in Girona and Lleida (Catalonia, NE-Spain) with special reference to fruit quality. Acta Hort. 658:333-339.

Bradshaw, T.L., L.P. Berkett, R.E. Moran, M.E. Garcia, H.M. Darby, R.L. Parsons, S.L. Kingsley-Richards, M.C. Griffith, S.C. Bosworth, and J.H. Gorres. 2016. Long-term economic evaluation of five cultivars in two organic apple orchard systems in Vermont, USA, 20062013. Acta Hort. 1137:315-321.

Bravin, E., A. Kilchenmann, and M. Leumann. 2009. Six hypotheses for profitable apple production based on the economic work-package within the ISAFRUIT Project. J. Hort. Sci. Biotechnol. 84(6):164-167.

Costes, E., P. Lauri, and J. Regnard. 2006. Analyzing fruit tree architecture: Implications for tree management and fruit production. Hort. Rev. 32:1-61.

Cummins, J.N. and H.S. Aldwinckle. 1983. Breeding apple rootstocks, p. 294-394. In: J. Janick (ed.). Plant breeding reviews. Springer, Boston, MA.

DeMaree, A. 1995. Critical factors in orchard profitability. Compact Fruit Tree 28:92-94.

DeMarree, A., T. Robinson, and S. Hoying. 2003. Economics and the orchard system decision. Compact Fruit Tree 36:42-49.

Elkins, R.B. and T.M. DeJong. 2002. Effect of training system and rootstock on growth and productivity of 'Golden Russet Bosc' pear trees. Acta Hort. 596:603-607.

Elkins, R.B., T.M. DeJong, K. Klonsky, and R. DeMoura. 2008. Economic evaluation of high density versus standard orchard configurations; case study using performance data for 'Golden Russet Bosc' pears. Acta Hort. 800:739-746.

Fazio, G., T.L. Robinson, and H.S. Aldwinckle. 2015. The Geneva apple rootstock breeding program. Plant Breed. Rev. 39:379.

Ferree, D.C. and I.J. Warrington. 2003. Apples: Botany, production and uses. CABI Publishing, Cambridge, MA.

Forshey, C. and D. Elfving. 1989. The relationship between vegetative growth and fruiting in apple trees. Hort. Rev. 11:229-287.

Goedegebure, J. 1993. Economic aspects of superintensive apple orchards. Acta Hort. 349:285294.

Greene, D.W. and S.A. Weis. 2001. Evaluation and growing of Honeycrisp in New England. Compact Fruit Tree 34(4):100-103.

Heijerman, G., P. Roelofs, and M. Groot. 2015. Profitability of the Dutch growing system of 'Conference'. Acta Hort. 1094:233-238.

Kappel, F. and R. Brownlee. 2001. Early performance of 'Conference' pear on four training systems. HortScience 36:69-71.

Kviklys, D., T.L. Robinson, and G. Fazio. 2016. Apple rootstock evaluation for apple replant disease. Acta Hort. 1130:425-430.

Lordan, J., S. Alegre, R. Montserrat, and L. Asin. 2017a. Yield and profitability of 'Conference' pear in five training systems in North East of Spain. Span. J. Agr. Res. 15(3):e0904.

Lordan, J., G. Fazio, P. Francescatto, and T.L. Robinson. 2016. Effects of apple (Malus $\times$ domestica) rootstocks on vigor and yield scion response. XI Intl. Symp. Integrating Canopy Rootstock Environ. Physiol. Orchard Systems. ISHS.

Lordan, J., G. Fazio, P. Francescatto, and T.L. Robinson. 2017b. Effects of apple (Malus $\times$ domestica) rootstocks on scion performance and hormone concentration. Scientia Hort. 225:96-105.

Lordan, J., P. Francescatto, L. Dominguez, and T.L. Robinson. 2018a. Long-term effects of tree density and tree shape on apple orchard performance, a 20 year study-Part 1, agronomic analysis. Scientia Hort. 238:303-317.

Lordan, J., M. Gomez, P. Francescatto, and T.L. Robinson. 2018b. Long-term effects of tree density and tree shape on apple orchard 
performance, a 20 year study-Part 2, economic analysis. Scientia Hort. https://doi.org/ 10.1016/j.scienta.2018.03.031.

Marini, R.P., J.L. Anderson, W.R. Autio, B.H. Barritt, J. Cline, W.P. Cowgill, R.C. Crassweller, R.M. Garner, A. Gauss, R. Godin, G.M. Greene, C. Hampson, P. Hirst, M.M. Kushad, J. Masabni, E. Mielke, R. Moran, C.A. Mullins, M. Parker, R.L. Perry, J.P. Prive, G.L. Reighard, T.L. Robinson, C.R. Rom, T. Roper, J.R. Schupp, E. Stover, and R. Unrath. 2006. Performance of 'Gala' apple trees on 18 dwarfing rootstocks: Ten-year summary of the 1994 NC-140 rootstock trial. J. Amer. Pomol. Soc. 60(2):69-83.

Merwin, I.A., R. Byard, T.L. Robinson, S. Carpenter, S.A. Hoying, K.A. Iungerman, and M. Fargione. 2001. Developing and integrated program for diagnosis and control of replant problems in New York apple orchards. New York Fruit Qrty 9(1):11-15.

Palmer, J.W. 1999. Light, canopies, fruit and dollars. 42nd Annual IDFTA Conf., Ontario, Canada.

Reig, G., J. Lordan, G. Fazio, M.A. Grusak, S. Hoying, L. Cheng, P. Francescatto, and T. Robinson. 2018. Horticultural performance and elemental nutrient concentrations on 'Fuji'grafted on apple rootstocks under New York state climatic conditions. Scientia Hort. 227:22-37.

Robinson, T., W. Autio, J. Clements, W. Cowgill, C. Embree, V. Gonzalez, S. Hoying, M. Kushad, M. Parker, and R. Parra. 2012. Rootstock tolerance to apple replant disease for improved sustainability of apple production. Acta Hort. 940:521-528.

Robinson, T. and S. Hoying. 1999. What we learned about tree support from the 1998 labor-day storm. New York Fruit Qrtly. 7(2):17-24.

Robinson, T. and S. Hoying. 2004. Performance of elite Cornell Geneva apple rootstocks in longterm orchard trials on growers farms. Acta Hort. 658:221-229.
Robinson, T.L. 2003. Apple orchard systems, p. 345-407. In: D.C. Ferree and I.J. Warrington (eds.). Apples: Physiology, production and uses. CABI, Wallingford, Oxon, UK.

Robinson, T.L. 2007. Effects of tree density and tree shape on apple orchard performance. Acta Hort. 732:405-414.

Robinson, T.L. 2008a. The evolution towards more competitive apple orchard systems in the USA. Acta Hort. 772:491-500.

Robinson, T.L. 2008b. Performance of pear and quince rootstocks with three cultivars in four high density training systems in the northeastern United States. Acta Hort. 800:793-801.

Robinson, T.L., H. Aldwinckle, G. Fazio, and T. Holleran. 2003. The Geneva series of apple rootstocks from Cornell: Performance, disease resistance, and commercialization. Acta Hort. 622:513-520.

Robinson, T.L., A.M. DeMarree, and S.A. Hoying. 2007. An economic comparison of five high density apple planting systems. Acta Hort. 732:481-489.

Robinson, T.L., G. Fazio, S.A. Hoying, M. Miranda, and K. Iungerman. 2011a. Geneva rootstocks for weak growing scion cultivars like 'Honeycrisp'. New York Fruit Qrtly. 19(2):10-16.

Robinson, T.L., G. Fazio, J. Lordan, P. Francescatto, and B. Black. 2016. 2015 Progress report: Evaluation of the Cornell-Geneva apple rootstocks and other promising apple rootstocks. Compact Fruit Tree 49(1):16-19.

Robinson, T.L., S.A. Hoying, and G. Fazio. 2011 b. Performance of Geneva $(\mathrm{R})$ rootstocks in onfarm trials in New York state. Acta Hort. 903:249-255.

Robinson, T.L., A.N. Lakso, and Z. Ren. 1991. Modifying apple tree canopies for improved production efficiency. HortScience 26:10051012.

Robinson, T.L., J. Lordan, D. Dragoni, A.N. Lakso, and P. Francescatto. 2017. Precision irrigation management of apple with an apple-specific
Penman-Monteith model. Acta Hort. 1150:245250.

Russo, N.L., T.L. Robinson, G. Fazio, and H.S. Aldwinckle. 2007. Field evaluation of 64 apple rootstocks for orchard performance and fire blight resistance. HortScience 42:1517-1525.

Sansavini, S. and S. Musacchi. 2002. European pear orchard design and HDP management: A review. Acta Hort. 596:589-601.

Sinoquet, H., G. Sonohat, A-M. Potel, P. Monney, and P-E. Lauri. 2008. Using virtual plants to estimate light distribution at intra-canopy scale in apple trees: Method presentation and assessment. Acta Hort. 803:225-234.

Sojkova, Z. and I. Adamickova. 2011. Evaluation of economic efficiency of the orchards investment project with respect to the risk. Agric. Econ. 57:600-608.

Torres, E., I. Recasens, J. Lordan, and S. Alegre. 2017. Combination of strategies to supply calcium and reduce bitter pit in 'Golden Delicious' apples. Scientia Hort. 217:179-188.

USDA. 2018. Natural Resources Conservation Service, United States Department of Agriculture. Web Soil Survey. 19 Mar. 2018. <https:// websoilsurvey.sc.egov.usda.gov/>.

Vercammen, J. 1999. Dossier Poire (2eme partie)Systemes de plantation et de taille pour le poirier conference. Fruit Belge 67(479):70 80.

Walsh, C.S., A.R. Ottesen, M.J. Newell, J.C. Hanson, and E.H. Leone. 2011. The effect of organic and conventional management programs on apple and Asian pear tree growth, productivity, expenses and revenues in a hot, humid climate. Acta Hort. 903:665672 .

Weber, M. 2001. Optimizing the tree density in apple orchards on dwarf rootstocks. Acta Hort. 557:229-234.

White, G. and A. DeMarree. 1992. Economics of apple orchard planting systems. Cornell Coop. Ext. Info. Bul. 227. 